\title{
目詰りによる透水性低下を考慮した 不織布系排水層の設計に関する一提案
}

\author{
林 英雄 ${ }^{1} \cdot$ 森 麟 \\ 1 正会員 （株）フジタ東京支店営業部部長（テ151 澁谷区干駄ヶ谷4-25-2） \\ 2 名誉会具 工博 早稲田大学名誉教授（广169 新宿区大久保3-4-1)
}

\begin{abstract}
盛土と軟弱な盛土基礎地盤の間や盛土内に敷設するサンドマット層やフイルター層に使用する良質のセレク 卜材の枯渴や材料採取. 運搬に伴う珙境保全の観点から, 最近セレクト材の代替としてジオテキスタイル排水 材が面排水材として採用されることが多い. しかしこれらの排水層の設計に当たっては排水材の目詰りの結果 生ずる透水性の低下を予測し，その低下量を考慮したうえで排水層の設計を行なうべきである. しかし現状の 設計では目詰りによる透水性の低下やその他重要な項目が落している.

このため。排水材の実状に合った透水性低下を予測する試験結果とその他不可欠な項目を考慮した不織布系 排水層の合理的設計についての提案をした.
\end{abstract}

Key Words : drainnage layer, nonwoven, field test, pearmeability, clogging, design,

earthfill embankment

1. まえがき

盛土法面部の安定のための盛土内部の水位低減や軟弱 粘性十盛十基礎地盤（以下，軟弱な基礎地盤）の圧密排 水に, 法面付近や盛十底面に面排水材を敷設する.

これらの排水層には，最近ジオテキスタイル排水層が かなり多く採用されつつあるが, 合理的設計法が提示さ れないので, ややもすると排水層の排水能力が不足する ために過剩間隙水圧の予想以上の上昇により, 法面の

'はらみ’や滑り, 軟弱な基礎地盤そのものの圧密時間 の遅延や残留沈下等の原因となる.

排水層の合理的な設計を阻んできた理由として，排水 層への浸透水の流入量や敷設後の排水能力に影響する排 水材の目詰りによる透水俰数の変化などの予測が困難で あったことが挙げられる.

このような状況の下でジオテキスタイル排水材が排水 層として多く使用されているので, その排水能力を求め る必要があり, 実状にあった方法の提示が要望される.

我が国でも地盤工学会基淮案 JSF931-199X, JSF932199X など排水材の通水性能試験方法が提案されている が, 目詰りによる透水性の低下については提示されてい ない. また市場にあるジオテキスタイル排水材は拘束圧 が作用したときの通水性能の変化を表示されていないも のもあり, 目詰りによる透水性低下について言及してい るものは殆ど見られないのが現状である.
排水層は土中からの流入水を排水し得る排水能力をも つことが必要であり, そのためには排水層が所要の動水 勾配と盛士荷重による拘束圧のもとで所要の通水性能を 有することである. また通水性能は土層から懸濁液が排 水層に流入し目詰りが発生することによって透水性が低 下するので，その減少量を予測して設計に反映すること が重要である.

筆者等は目詰りによる透水性の低下を予測するために 現場の状況を出来るだけシュミレートできる試験方法を 提示し，その方法に基づいた目詰りによる透水性の低下 予測を数力所の現場で実測検証した

本論文の目的は不織布系排水層を用いて盛土の法面安 定上必要な排水と軟弱な基礎地般からの圧密排水を目詰 りなども考慮して, 条件が最も厳しくなる時期において 処理できるような設計法を提示することである.

\section{2. 設計上の基本事項}

\section{(1) 概要}

盛土の排水層に流入する流入水量は降雨が浸透し盛土 中を降下浸透して排水層に流入する流入水量と軟弱な基 礎地盤が圧密排水されて排水層に流入する圧密排水量を 対象とする.

排水層の排水能力は土粒子の流入総量の増加とともに 目詰りによって低下するが, 最終的に土粒子の流入が無 
くなり“最終安定段階”１に達する．この最終安定段 階に達するまでに，流出した単位面積当たりの土粒子総 量を“土粒子流入負荷量”とし，この段階までの透水量 を“限界透水量”と呼ぶこととする.

排水層の設計は排水能力と排水すべき総流出水量の関 係が最も厳しくなる状態に当たる設計対象時期について 行なうものとする. 良質の基礎地盤上や盛土中に敷設す る排水層の場合と軟弱な基礎地盤上に敷設する場合につ いて，それぞれ定めた設計対象時期において，排水層は 排水すべき総流出水量を安全に処理できる排水能力をも たなければならない.

\section{（2）排水材の選定}

排水材に使用されるジオテキスタイルの種類は不織布, 不織布の複合型, 織布, 複合管路型に分類されそれぞれ に数種類がある.

排水層の構造摸式図を 図一 1 に示す.

一般に面排水層には流入水が表面（鉛直）流入し面内 (水平) 流下条件で通過する. そこで太い短緎維 (籼加 V) の不織布, 細い短織維(利加比) の不織布, 不織布 の複合型 (コードカーペットの表面にスパンボンド不織 布を固定），複合管路型を用いて，所定の懸濁液を鉛直 方向に表面流入・裹面流下条件で所定量の土粒子を所定 の拘束圧下で負荷する目詰り試験 ${ }^{2)}$ を行なった. 排水 材の通水性能は土粒子の目詰りによる透水性の低下に支 配されるが, 排水層に流入する土粒子流入負荷量は390 $\sim 430 \times 10^{-6} \mathrm{~g} / \mathrm{cm}^{2}$ （本章 (4) で後述）を設定すれ ばよい.

既に発表した研究 ${ }^{2)}$ によると, 上記の土粒子流入負 荷量では目詰り後の鉛直方向通水性の低下は排水材の構 造形式による差異は殆どなく非常に小さく，排水層に接 する盛十層の透水係数 $10^{-4} \mathrm{~cm} / \mathrm{s}$ のオーダー以上であっ た.このことから, 実用的には鉛直方向の透水性の低下 を無視してよいことが判っている.

問題となる面内方向の通水性能は拘束圧の増加と土粒 子の負荷量の増加とともに目詰りにより低下する. また 小さい拘束圧のもとで通水性能が大きいものほどその低 下量は著しいが，低下後の通水性能の絶対値としては大 きい值を維持していることが判かった ${ }^{2)}$.

このことから目詰り前と後ともに通水性能の大きい順位 は複合管路型, 不織布複合型, 不織布であった.

排水材を選定する場合は排水材そのものの通水性能が 大きく，かつ目詰りによる透水性低下が少なく，経済性 の良いことを条件として選定することが重要である.

一般に織布は通水性能が小さいので除外し, 複合管路型 は通水性能が非常に大きいが材料費が高い難点がある.

これに対し不織布と不織布複合型は目詰り後も比較的 通水性能が確保でき, 安価である利点を重視して, ここ

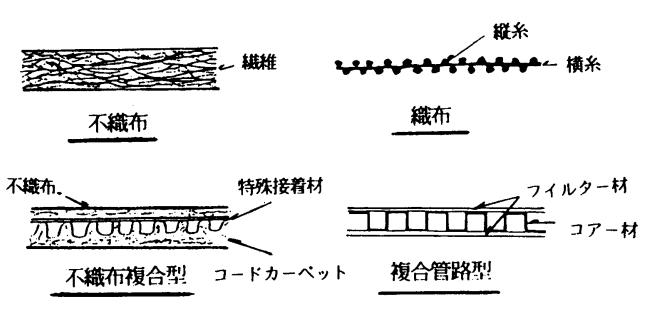

困一１排水層の構造摸式四

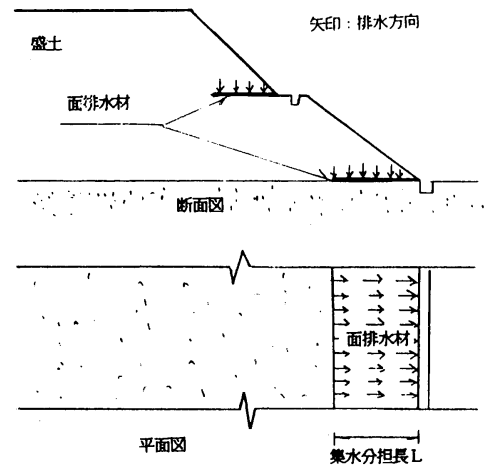

（A） 良質の盛十基礎地盤の場合 （排水層を法面付近のみに敷設する場合）

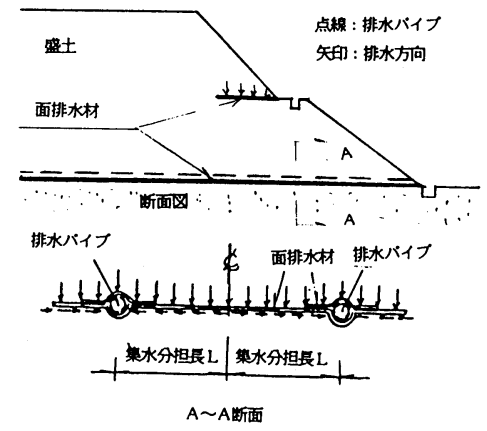

（B） 軟弱粘性十盛十基礎地盤の場合 （排水層を盛十底面の全面に敷設する場合） 図-2 排水層の数設㮃造

ではこれらの不織布系排水材（一枚の厚さ約 $1 \mathrm{~cm}$ 以下の 製品）が適切と考え，これらの中から選定するものとす る.

\section{（3）排水層の敷設構造}

図一2 に排水層の敷設断面構造を示す. 比較的良質 な盛十基礎地盤や盛土材の場合には，図一2 (A) に当たる排水材の部分敷設を採用する.

敷設構造は盛十の法面の安定が目的で排水材を法面付近 に部分敷設する. 従って, この場合の集水分担長Lは排 水材の長さとなる.

軟弱粘性土の基礎地盤上に盛土を構築する場合には, 
図一2（B）に示すように盛十基礎地盤面について のみ全面に敷設する．これは基礎地盤からの厈密排水に 対処し，この全面敷設の場合の集水分担長 Lは排水管路 間隔の 1 / 2となり, 排水管路には有孔パイプ等を使 用する. また盛土本体部は部分敷設とする.

排水層は 図一-1（A)，（B） 共に奥行に当たる 盛十軸方向には連続敷設とする.

\section{（4）排水材の目詰りによる通水性能低下予測値}

排水材の目詰りによる通水性能低下後の予測值は良質 の基礎地盤上や盛土中に敷設する場合と軟弱な基礎地盤 上に直接敷設する場合に分けて，排水材にそれぞれ設定 する土粒子流入負荷量を鉛直流入・面内流下方式で流入 させる “目詰り試験” 1)（本節d）に記載）により求 める.

\section{a）盛士中及び良質の基礎地盤上に直接敷設する場合}

排水材の通水性能は負荷された土粒子の目詰りによっ て生じる透水係数の低下に支配される.

浸透水からの土粒子流入負荷量は土質と締固め含水比 により大きく支配されるが, 締固め含水比の最適含水比 からのずれ率と土柆子流入負荷量との関係を土質別に

図一 $3^{11}$ に示す. 図より，シル卜質砂の土粒子流出 量が最大值を示す $390 \times 10^{-6} \mathrm{~g} / \mathrm{cm}^{2}$ であることから， 浸透水からの土粒子流入負荷量の安全側の設定值として $390 \times 10^{-6} \mathrm{~g} / \mathrm{cm}^{2}$ とする.

\section{b) 軟弱な基碟地盤上に直接旉設する場合}

垂直ドレーンを打設する場合としない場合とがあり， それぞれ土粒子流入負荷量が異なる.

(1)垂直ドレーンを打設しない場合

この場合は既に発表した研究 3)，4) から，軟弱な基礎 地盤の圧密排水による土粒子流入負荷量は $10 \times 10^{-6} \mathrm{~g} /$ $\mathrm{cm}^{2}$ とすればよく, 上部盛土からの負荷量の $390 \times 10^{-6}$ $\mathrm{g} / \mathrm{cm}^{2}$ を合せて $400 \times 10^{-6} \mathrm{~g} / \mathrm{cm}^{2}$ を設定する.

(2)垂直ドレーンを打設する場合

盛土基礎地盤が厚い軟弱な粘性土層でドレーンを打設 する場合，ドレーンから盛十基礎地盤上に敷設した排水 層に負荷される土粒子流入負荷量については次のように なる.

基礎地盤上の排水層への土粒子流入負荷量はドレーン 長，打設ピッチ，ドレーン材により異なり，更に下記に 述べる垂直ドレーンからの土柆子流出率はドレーン材に よって異なる．このため, ここでは汎用されている不織 布系ドレーン材を使用するとし, ドレーン長 $20 \mathrm{~m}$, 幅 $10 \mathrm{~cm}$ の帯状のものを使用し，打設ピッチを正方形配置で $1.0 \mathrm{~m} \times 1.0 \mathrm{~m}$ とした場合，土粒子負荷量を次のように設定 する.

圧密排水による垂直ドレーン表面への土粒子負荷量は $10 \times 10^{-6} \mathrm{~g} / \mathrm{cm}^{2}$ とし, 垂直ドレーン (幅 $\left.10 \mathrm{~cm}\right)$ の両面

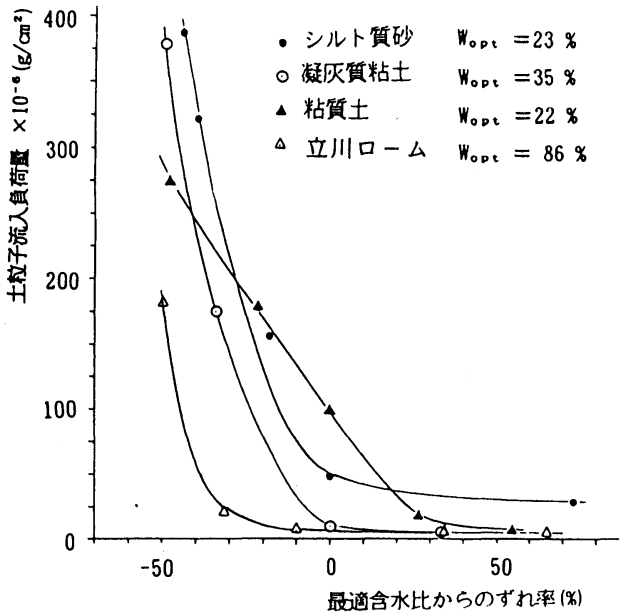

\section{図一3 締固め含水比の最適含水比からのずれ率 と土柆子流入負荷量}



\section{图一４土柆子流入流出率}

から土粒子が流入上昇して排水層に負荷される．このド レーンからの土粒子流入負荷量は次のようになる.

土粒子流入負荷量 $=$ (垂直ドレーンの表面積 $\times$ 土粒子 負荷量）／垂直ドレーン1本当たりの分担面積

従って，垂直ドレーンからの土粒子流入負荷量は40X $10^{-6}\left(\mathrm{~g} / \mathrm{cm}^{2}\right)$ となる。

垂直ドレーンに負荷された土粒子は全部排水層に流入 するのではなく，垂值ドレーン自身に目詰りするので減 少する. この状況を実験で調査した結果を 図一4に 示すが，この図は垂直ドレーンへの土粒子流入総量 (本 節c）に後述）とドレーンの流出端での流出率との関係 である.

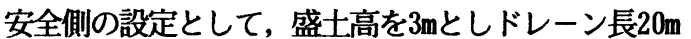
の $2 / 3$ の深さの拘束圧 (有効水平土圧) を $1 \mathrm{kgf} / \mathrm{cm}^{2}$ とすると, 四から土流子流出率は複合型、不織布でそれ ぞれ88\%，67\% となり，面排水層への土粒子流入負荷量 はそれぞれ $35 \times 10^{-6}$ と $27 \times 10^{-6} \mathrm{~g} / \mathrm{cm}^{2}$ となる. 
以上の結果から，不織布系ドレーン材の場合，垂直長 さが $20 \mathrm{~m}$ 程度であれば, 垂直ドレーンから面排水層への 土粒子流入負荷量は約 $30 \times 10^{-6} \mathrm{~g} / \mathrm{cm}^{2}$ 程度とすればよ い. この外に垂直ドレーンによらず直接盛十基礎底面か らの圧密排水による負荷量 $10 \times 10^{-6} \mathrm{~g} / \mathrm{cm}^{2}$ と上部盛土 からの負荷量 $390 \times 10^{-6} \mathrm{~g} / \mathrm{cm}^{2}$ を加えて, 土粒子流 入負荷量は $430 \times 10^{-6} \mathrm{~g} / \mathrm{cm}^{2}$ を設定しておけばよいこ とになる.

同様にして垂直ドレーン長が15m のときの土粒子流入負 荷量は $420 \times 10^{-6} \mathrm{~g} / \mathrm{cm}^{2}$ を設定すればよい.

従って, 上記の各種ケースの土粒子流入負荷量は390 〜30 $\times 10^{-6} \mathrm{~g} / \mathrm{cm}^{2}$ の範囲である.

\section{c）排水層下流端の土粒子流入総量}

排水層の単位面積当たり $390 \sim 430 \times 10^{-6} \mathrm{~g} / \mathrm{cm}^{2}$ の 土粒子流入負荷量の土粒子が表面から流入し，排水層に 目詰りを生じながら下流端から流出する.

このとき面内方向の透水距離が最大である下流端での 単位幅当りの土粒子流入総量（以下土粒子流入総量と呼 び, 排水層の上流端からの距離と土柆子流入負荷量の積 より求める）が最も大きくなり，排水層全体の透水性は この下流端付近の目詰り後の透水性に支配される.

排水層の目詰り後の透水性は実用面から最大の集水分 担長が概ね $5 \mathrm{~m}$ 程度となるので，上記の土粒子流入負荷量 の場合，設計条件での現場の土粒子流入総量は 200,000 $\times 10^{-6} \mathrm{~g} / \mathrm{cm}$ 程度以下となる.

\section{d）目詰り試験方法と通水性能の予測}

排水層の目詰りの結果生ずる通水性能の低下後の予測 値は上記の土粒子流入総量を排水材に負荷する目詰り試 験により求められる.この試験は既に詳しく発表 ${ }^{~}$ し し てあるが, 要約すると次の通りである.

(1)目詰り試験方法

目詰り後の排水層の通水性能は流入土粒子の目詰りで 生じた排水層の面内方向透水係数の分布と排水層の層厚 により支配される.こうした排水層の目詰りによる通水 性能低下現象のメカニズムを室内試験で再現できるよう な目詰り試験装置を考案した。

この装置を用いて測定した目詰り後の供試体の透水係 数分布と別途行なう排水材の加厈試験 (24時間載荷) で の厚さの測定結果から, 次項(2)で述べる方法により現場 の排水層の通水性能を予測する.

試験に用いる供試体は長さ $30 \mathrm{~cm}$, 幅 $10 \mathrm{~cm}$ 帯状のもの で, これを半円柱形の2 個のブロック（1 つは多数の水 平孔のあるもの, 1 つは無孔のもの) で挟んで三軸室に セットしメンブレンを介して，液圧によって排水材に現 場で作用する拘束圧を与える.

本節 c）で述べたほぼ最大值に当たる200,000 $\times 10^{-6}$ $\mathrm{g} / \mathrm{cm}$ の土粒子流入総量を有孔の半円柱ブロックを通し て所定の濃度, 粒度の䑨濁液を, 一定の水頭差のもとで



四一5 目詰り陚垟装琵

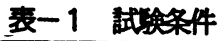

\begin{tabular}{|l|l|}
\hline 供試体寸法 & $30 \mathrm{~cm}($ 長さ $) \times 10 \mathrm{~cm}($ 幅 $)$ \\
\hline 拘束厌 & 最大土被り圧 $(5 . \quad(6)$ 参照 $)$ \\
\hline 土粒子流入総量 & $200,000 \times 10^{-6} \mathrm{~g} / \mathrm{cm}($ 下流端 $)$ \\
\hline 懸濁液の流入量 & 濃度 $40 \mathrm{ppm}$ のとき $50 \times 10^{3} \mathrm{cc}$ \\
\hline 土粒子濃度 & $20 \sim 40 \mathrm{ppm} \quad($ 一定濃度 $)$ \\
\hline 土粒子粒度 & 最大粒径 $80 \mu \mathrm{m}$ \\
\hline & $D_{60}=20 \mu \mathrm{m}$ 程度 \\
& $D_{10}=5 \mu \mathrm{m}$ 程度 \\
\hline 水頭差 & $40 \mathrm{~cm}$ \\
\hline
\end{tabular}

表面流入・面内流下条件で供試体に流入させる.

このようにすれば，土粒子流入総量が少ない場合にも対 応できる.

目詰り試験の試験条件は既に検討した結果 ${ }^{11}$ ，5) から

表一1 に示す通りとする. また懸濁液の流入開始は 排水材の変形が収束する24時間載荷後とする.

排水層の目詰り後の透水係数の分布を実情に近い值と して表示するために, $30 \mathrm{~cm}$ の供試体を 図-8 に示す 4 つのブロックに予め切断したものをセットする.

既に述べたように，現場排水層の下流端の最大土粒子 流入総量は200,000 $\times 10^{-6} \mathrm{~g} / \mathrm{cm}$ であるので, この土粒 子流入総量を供試体に流入する．供試体長は $30 \mathrm{~cm}$ である ので，下流端に土粒子流入総量200,000 $\times 10^{-6} \mathrm{~g} / \mathrm{cm}$ を 負荷するには，この場合単位面積当たりの土粒子流入負 荷量は土粒子流入総量を供試体長で除して $6667 \times 10^{-6} \mathrm{~g}$ $/ \mathrm{cm}^{2}$ となる.

このことから憅濁液の濃度を40ppm $\left(10^{-6} \mathrm{~g} / \mathrm{cm}^{3}\right)$ とした場合, 懸攞液の流入量は土柆子流入負荷量に供試 体の面積を乗じた值を濃度で除すと $50 \times 10^{3} \mathrm{~cm}^{3}$ となる.

目詰り試験後, ブロック別の面内方向透水係数の湘定 は流入後の各ブロックの供試体を取り出して, 2 個の無 孔半円柱に挟んで流入時と同じ拘束圧の下で透水試験を 
行なうことにより求める.

(2)通水性能の予湘

通水性能は 4.（5）で後述するが, 排水層の透水係 数と層厚の積から求める. 現場で作用する拘束圧のもと での層厚は上記の加圧試験の值を用いる.

排水層の目詰り後の透水㐿数の予測值は以下の上うに して求める. 目詰り試験て求めた 4 つの各ブロックの面 内方向透水係数の測定値と各ブロックの土粒子流入総量

$\left(200,000 \times 10^{-6} \mathrm{~g} / \mathrm{cm}\right.$ と 図-8 の寸法比の積)の 算定値を用いて，土粒子流入総量と面内方向透水保数の 関係図（不織布，不織布複合型の場合，図-9 参照) を作成する.

この場合の各ブロックの土粒子流入総量 $\left(\times 10^{-6} \mathrm{~g}\right.$ ／cm）は下流端ブロックからブロックAでは200,000， Bでは167,000，Cでは133,000，Dでは67,000となる

種々の集水分担長に対応する現場排水材の目詰り後の 透水保数 $\mathrm{k}_{\mathrm{n}}$ を 四一9 を用いて, 次のようにして求 める. まず現場排水層の集水分担長を選定する.この場 合に対する排水層下流端での土粒子流入総量は必ずしも 前出の200, $000 \times 10^{-6} \mathrm{~g} / \mathrm{cm}$ ではなく, 設定した土粒 子流入負荷量と集水分担長により求めた值とする.

また現場排水層の透水係数 $\mathrm{k}_{\mathrm{n}}$ を求めるために，現場 排水層の集水分担長を 四-8 の寸法此で $\mathrm{A}, \mathrm{B}, \mathrm{C}$, Dの 4ブロックに分割し, 分割寸法比と上記で求めた下 流端の土柆子流入総量との積から, 各ブロック別の土粒 子流入総量を求める.

ここで求めた現場排水層の各ブロック別の土粒子流入 総量に対応する面内方向透水俰数を，予め選定した排水 材の目詰り試験結果から作成した 困一9 の関㐿図を 用いて求める.

これらの面内方向透水倸数と現場排水層のブロック長 から, 後述する式 $(4-2)$ により, 排水層の目詰り後 の透水係数 $\mathrm{k}_{\mathrm{n}}$ を求める.

\section{3. 設計の基本方針}

排水層の設計は盛土中の浸透水や軟弱な基碳地盤から の圧密排水を盛十外に支障なく排水するように, 排水層 の配置（鉛直設置間隔等），敷設構造，排水材を選定し 排水層の表面加流入水を面内方向に通過させ，下流， 端での総流出水量を支障なく排水し得る排水能力を有す るような排水層を決定する. そのため集水分担長, 排水 材の厚さ等を試行錯誤により適切な設定值を決定する。

排水層は盛土工事開始加ら供用後の間に排水層に流入 する流入水量と排水層の排水能力力释時的に变化するの で, 排水層は設計上で籗しくなる設計対象時期において 排水層の下流端での総流出水量を支障なく排水し得るよ うに排水能力を決定する。
王密による排水量はかなり初期の段階に最大値となり その後逐次低減する. また排水層の通水能力は排水の初 期段階での最大值から，排水層に流入する土粒子の増加 とともに低下し, 盛土完了時の盛土荷重による拘束厈で の最終安定段階において最小となる.

このため各設計対象時期において設定する拘束厈のも とでの層㫗と目詰りにより低下した透水㐿数のもとで, 設計対象時期（最も危険になる時期）での総流出水量を 安全に流出できる排水能力を保持する排水層を決定する。

排水能力の算定に必要な動水勾配は排水層上流端の最 高水位を法面安定などから経験的に定めた値とする。

排水層の設計の基本的な手順を示すと 困一 6 のよ うになる.

\section{4. 設計上必要な項目の数値設定及び算定}

前章の 図一6 から，排水層の設計に当たって必要 な項目の数値設定及び算定について述べる.

\section{（1）排水層の鈆直㽞已置間隔と長さの選定}

盛十基礎地盤が良好の場合には 図-2（A）の敷 設構造を選定し，排水層の鉛直配置間隔は経験的に選定 され, 高い盛土の場合, $5 \mathrm{~m} \sim 6 \mathrm{~m}$ 程度の間隔に設けら れる小段の高さに設置する. また排水層の敷設長（盛土 横断方向の幅）については約 $5 \mathrm{~m}$ 程度とし, これ以下に することは法面安定上不適当である. また盛十基礎地盤 か漸弱粘性土の場合には 図一2（B）を選定し，盛 土底面上の排水材は全面に敷設し，法面付近に敷設する 排水層は 困-2（A） の場合と同様とする.

\section{（2）土粒子流入負荷量と土粒子流入総量の設定}

\section{a）土粒子流入負荷量}

土粒子流入負荷量は排水層に流入する単位面積当たり の土粒子の流入量である.

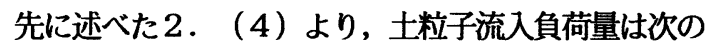
三つの場合により異なる. 盛土中及び良質の基礎地盤上 の場合, $390 \times 10^{-6} \mathrm{~g} / \mathrm{cm}^{2}$ とする. また軟弱な基整地 盤上の場合, 垂直ドレーンを打設しないとき $400 \times 10^{-6}$ $\mathrm{g} / \mathrm{cm}^{2}$ とし, 重直ドレーンを打設するとき, ドレーン 長 $20 \mathrm{~m}$ では $430 \times 10^{-6} \mathrm{~g} / \mathrm{cm}^{2}$ とし, $15 \mathrm{~m}$ では $420 \times$ $10^{-6} \mathrm{~g} / \mathrm{cm}^{2}$ とする.

なお土柆子流入負荷量は土粒子流出試跧 ${ }^{1)}$ を行う場 合は試呀結果から設定する.

b) 土粒子流入総量の設定

下流端での土粒子流入総量は上記の土粒子流入負荷量 と5. (4) に述べる集水分担長との積から求める.

これまでの経験から, 集水分担長は約 $5 \mathrm{~m}$ 程度となる ので，土粒子流入負荷量を $400 \times 10^{-6} \mathrm{~g} / \mathrm{cm}^{2}$ に設定する 
（設計対象時期の総流出水量の算定）

（雨水による浸透水量）（压密排水量）
(設計対象時期の排水能力の設定)



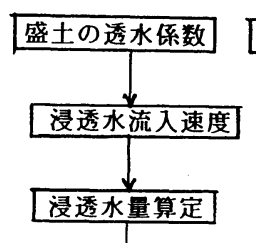

時間 盛土高・沈下関係

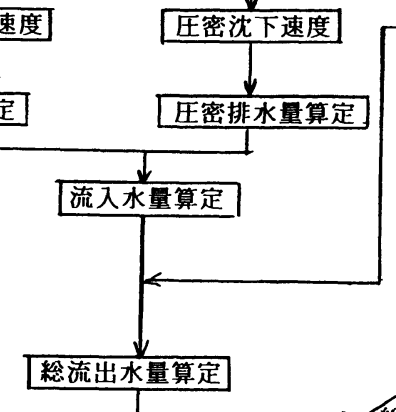

集水分担長設定 单位幅当り土柆子流入総量設定

盛土高

$\rightarrow$ 層厚の設定 (加压試的) $\rightarrow$ 拘束圧


面内方向透水係数分布設定（目詰り試験）

排水層の透水係数算定

排水層の通水性能算定

比

総流出量排水

継手の必要重ね長の設計

因一6 排水層の設䂥手順

と, 一般の場合, 最大土粒子流入総量は200, $000 \times 10^{-6}$ $\mathrm{g} / \mathrm{cm}$ 程度とすればよい.

\section{（3）排水層の設計対象時期の設定}

\section{a）良質の盛士基礎地盤上と盛士中の排水雷の場合}

良質の基礎地盤上と盛土中に敷設する排水層の場合は

図一2（A） の部分敷設を選定するのが適当である.

この場合, 排水層への単位時間の浸透水量, 即ち流入 水量は盛土中の浸透水の降下速度で決まる．これは降雨 強度に拘らず盛土に用いた土質の飽和透水㐿数の $1 / 2^{6)}$ に相当する.

従って盛十施工時も, 供用時も, 流入速度は一定であ り, 排水層への単位時間当たりの流入水量は変化しない と考えてよい.

このため排水層の排水能力が最も小さくなる盛十完了 後の盛土荷重による拘束圧下での最終安定段階のみを設 計対象時期とする.

\section{b）軟弱な基整地盤上の排水畨の場合}

(1)設計対象時期

盛土基礎地盤が乾弱粘性土のとき，図一2（B) のように盛十底面に全面敷設する排水層には，基礎地盤 の圧密排水と盛十からの雨水による浸透水が流入する.

軟弱粘性土からの時間当りの圧密排水量は盛土の最大 沈下速度の時点で最も多く, この量は雨水による浸透水 量に比べて遥かに大である. その後排水量は厈密の進行 につれて減少する.この最大沈下速度となる時期は排水 量が最も大きくなるので, この時期において排水能力を
検討する必要がある.

この時期は盛土工事の初期に当たるので排水層の拘束 圧も小さく, 目詰りも僅かで通水性能の低下は少ない. この設計対象段階を初期段階時期とする.

次に，第2 番目として，排水材の通水性能が最小とな る盛十完了後の盛土荷重による拘束圧下での最終安定段 階でも検討が必要である.

この場合，盛士底面に作用する拘束圧は盛士本体底面 部と法面部に分け, 本体底面部の拘束圧の作用幅は盛土 の天端幅に盛十高さの $1 / 2$ を左右に加えたものとし, 拘束圧は盛十高相当荷重とする.

また法面底面部の拘束圧は本体底面部の $1 / 2$ とする.

更に，第3番目として，盛十基礎地盤の支持力が非常 に小さい場合など，盛十速度が制限され，盛土に特別長 時間を要するときには盛十完了時に達するより早く最終 安定段階に到達する場合が有り得る.

このときの压密排水量は盛十完了時よりも多く危険サ イドになることがあるので，この時点も設計対象時期に なり得る.

この場合, 盛土本体底面部と法面底面部では最終安定 段陼到達時間が大きく異なるので，この二つの部分で別 個に扱うことになる.

（2最終安定段階到達時間の算定

上記(1)の第3番目の検討が必要か否かの決定には最終 安定段階時期の算定が必要となる.

最終安定段階時期とは浸透水による土粒子の流出状況 は各土質とも透水開始とともに最大濃度となり急激に低 
下するが，その後は逐次緩やかに減少しゼロに近づく． そして土粒子の流出か殆ど止まる状態となる.この状態 に到達したときを最終安定段階時期とする.

最終安定段階時期に達するまでの時間は2.（1）で 前述した限界透水量に相当する降雨が盛土に浸透し, そ の間に盛土された層厚を降下浸透して排水層に流入完了 するまでの時間となる.

表一2 に限界透水量と降下浸透速度の2 倍に当たる 飽和透水係数を示す.

一例として立川ローム（表一2 参照）の場合につ いて最終安定段階到達時間を算定する. 限界透水量は締 固め含水比が低いほど大きくなり $1.5 \sim 6.0 \mathrm{~cm}^{3} / \mathrm{cm}^{2}$ であるが, 現場での締固め含水比は自然含水比に近い含 水比で施工され, 自然含水比での限界透水量はおおむね 上記の值の平均值位である. このことから限界透水量は

$3.7 \mathrm{~cm}^{3} / \mathrm{cm}^{2}$ とし, この水量に相当する雨水が盛十に 浸透するに要する時間 $\mathrm{t}_{1}$ は限界透水量を 1 日当たり浸透 量で除した値である.

次に 1 日当たり浸透量を求める. 日本の平均年間降雨 量は $1,700 \mathrm{~mm}{ }^{7)}$ である. 降雨の年間浸透量は年間降雨量 から年間蒸発量 (降雨の約20\%) 8) と流出量 (流出係数 は盛土施工段階の状況を考慮して, 平坦な耕地の0.45〜 0.60 の平均値 0.53 を設定) ${ }^{9}$ とを差し引くと $459 \mathrm{~mm}$ と なる. この年間浸透量を年間日数で除すと 1 日当たり

$1.3 \mathrm{~mm}$ となる. 圧密の排水状況を考えると, 最終安定段 階が早期になるほど安全側となるので，上記の年間浸透 量が毎日平均して地表から浸透すると考える.

このことから限界透水量に相当する雨水が盛士に浸透す るに要する時間 $\mathrm{t}_{1}$ は 0.9 ケ月となる.

次に雨水が上記 $t_{1}$ 時間に盛土された土層厚を降下浸透 して排水層に到達するに要する時間 $\mathrm{t}_{2}$ は上記の土層厚を 降下浸透速度（最終浸透能）で除した值となる. 盛土の 盛り立て速度を暦日当たり0.3〜0.5 m (平均値 $0.4 \mathrm{~m}$ ) とすると, $t_{1}$ の時間に盛土される土層厚は $11.2 \mathrm{~m}$ となる.

これより土層厚と浸透速度 $8.0 \times 10^{-6} \mathrm{~cm} / \mathrm{s}$ とから降 下浸透時間 $\mathrm{t}_{2}$ は 54.0 ケ月となる. 盛土開始から最終安定 段階に達するまでの時間は $t_{1}$ と $\mathrm{t}_{2}$ を合せて54.9 ケ月とな る. 法面底面部は時間 $\mathrm{t}_{1}$ 中での土層厚は上記の $1 / 2$ に 考えると, 最終安定段階到達時間は約半分の 27.5 力月と なる.

同様に各土質について $t_{1}, t_{2}$ を求めて, 土層厚と最終 安定段階到達時間の関係を 図一 7 に示す.

但し，上記の土層厚より盛土高が低い場合には, 盛土 高を土層厚とし， $t_{1} ， t_{2}$ を求める.

（4）設計対象時期における流入水量と総流出水吾の算 定

設計対象時期において排水層への流入水量と集水分担

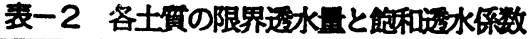

\begin{tabular}{|l|l|c|}
\hline 土 質 & 限界透水量 & 飽和透水係数 \\
\hline & $\left(\mathrm{cm}^{3} / \mathrm{cm}^{2}\right)$ & $(\mathrm{cm} / \mathrm{s})$ \\
シル卜質砂 & $4.0 \sim 8.0$ & $1.5 \times 10^{-4}$ \\
凝灭質粘土 & $0.3 \sim 1.6$ & $5.8 \times 10^{-6}$ \\
粘質土 & $2.0 \sim 6.0$ & $8.8 \times 10^{-6}$ \\
立川ローム & $1.5 \sim 6.0$ & $1.6 \times 10^{-5}$ \\
\hline
\end{tabular}

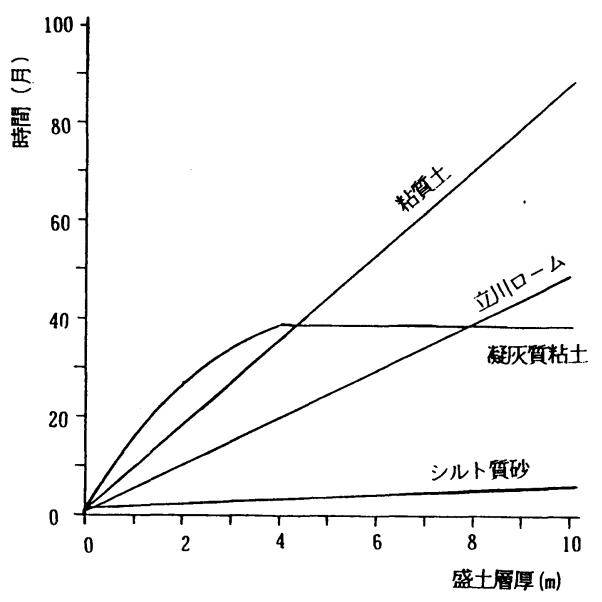

困-7 盛土層厚と最柊安定段陼到達時間

長との積から排水層下流端での総流出水量を求めるため に，各設計対象時期での流入水量について検討する.

排水層に流入する流入水量は盛土からの浸透水と盛土 基礎地盤の軟弱粘性土の圧密排水を対象とするが, 圧密 排水量は時間の経過につれて変化する.

排水層を盛士基礎地盤上に敷設する場合, 基礎地盤が 良質のときは雨水による浸透水のみが流入し，基礎地盤 が軟弱粘性土のときは浸透水に加えて多量の厌密排水が 流入する．また盛十中に排水層を敷設する場合は基礎地 盤の状態に拘らず雨水による浸透水のみが流入する.

a）良質の盛士基礎地盤上と盛士中排水層への流入水量 良質の盛十基礎地盤上と盛十中に敷設する排水層の設 計対象時期は4.（3）a）で述べた盛十完了後の最終 安定段階のみである. この場合の排水層の単位面積当た りの流入水量は既に4.（3）a）に述べたもので, 降 雨強度に拘らず盛土材の飽和透水係数の $1 / 2$ の降下速 度に単位面積を乗じた值に相当する.

流入水としては浸透水のみであり，この水量は年間を 通して降雨量がかなり均等に降る可能性を考慮して, 盛 土開始から供用時まで変わらないとする.

b）軟弱な基礎地盤上の排水層への流入水量

流入水量は各設計対象時期とも浸透水量と圧密排水量 を合せた量とする.

この内, 浸透水量は本節a）の場合と同じ量とする.

盛士荷重による軟弱粘性土の圧密排水量は盛土高と時 
間，沈下量との関係を示す計算による予想沈下曲線から 各設計対象時期での沈下速度を算定し圧密排水量を求め る. このとき沈下曲線は本体部と法面部に分ける.

本体部は各設計対象時期での盛土高さ相当荷重とし, 法面部では本体部の $1 / 2$ とする.

圧密条件は一次元圧密でかつ一次圧密のみとする.こ のとき安全側に考えて, 圧密層は飽和状態にあるものと し, 流入水量は沈下体積に相当し, 側方流動はないもの とする.

\section{c）設計対象時期における站流出水量}

排水層の下流端における単位幅当り総流出水量 $Q$

$\left(\mathrm{cm}^{3} / \mathrm{s} . \mathrm{cm}\right)$ は排水層表面から単位時間に流入する流 入水量 $\mathrm{q}\left(\mathrm{cm}^{3} / \mathrm{s} \cdot \mathrm{cm}^{2}\right)$ に集水分担長 $\mathrm{L}(\mathrm{cm})$ を乗じ た値となる.

\section{（5）排水層の通水性能と排水能力の設定}

排水層は各設計対象時期における総流出水量を処理で きる排水能力をもたなくてはならない.

この排水能力は排水層の通水性能と排水層の動水勾配 の積に相当する. この排水層の排水能力qは排水層の動 水勾配 $i$ (本節 e）参照) と排水層に作用する盛士荷重 （拘束圧）のもとでの排水材の層岸 $\mathrm{d}$ と排水層の面内方 向透水係数 $\mathrm{k}_{\mathrm{n}}$ とにより次式で表わされる.

$$
\begin{aligned}
& \mathrm{q}=\mathrm{d} \cdot \mathrm{k}_{\mathrm{h}} \cdot \mathrm{i}\left(\mathrm{cm}^{3} / \mathrm{s} . \mathrm{cm}\right) \quad(4-1) \\
& \mathrm{K}_{\mathrm{n}} \text { ：排水層の面内方向透水係数 } \\
& \text { i : 動水勾配 } \\
& \mathrm{d} \text { : 層厚 }
\end{aligned}
$$

上式で $\mathrm{d} \cdot \mathrm{k}_{\mathrm{h}}$ が排水層の通水性能にあたる.

\section{a ）良兵の盛士基䂣地盤上と盛士中の排水層の通水性能}

良質の盛土基礎地盤上と盛十中に敷設する排水層は法 面下の部分敷設であるので, 通水性能は排水層鉛直間隔 の1/2 の土被り荷重による拘束圧での排水層の層厚と最 終安定段階の透水係数の積である.

排水層を基礎地盤上にのみ敷設する場合は拘束圧を盛 土荷重の $1 / 2$ とする. 最終安定段階での排水層への土粒 子流入負荷量は土質にかかわらず設定値の $390 \times 10^{-6} \mathrm{~g}$ / $\mathrm{cm}^{2}$ である.

\section{b）軟弱な基硭地盤上の排水層の通水性能}

前に述べた $2 〜 3$ 種の設計対象時期について通水性能 を設定する必要がある.

各設計対象時期の盛土荷重を本体部と法面部に分け, それぞれの直下に当たる排水層別に層肎と透水係数の積 から通水性能を求める.

各設計対象時期での拘束圧は4（（3）b）(1)で述べ たように，本体底面部は各設計対象時期での盛土高さ相 当荷重とし, 法面底面部は本体底面部の $1 / 2$ とする.

また最終安定段階での土粒子流入負荷量は压密排水に よる土粒子負荷があるので 2．（4）b）により設定す

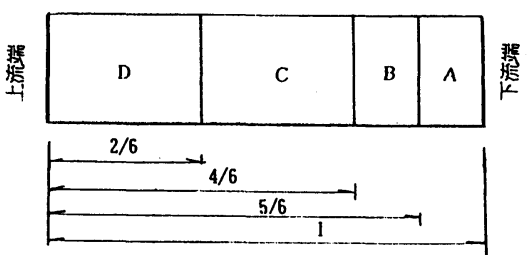

図-8 排水層のプロック分割と寸法此

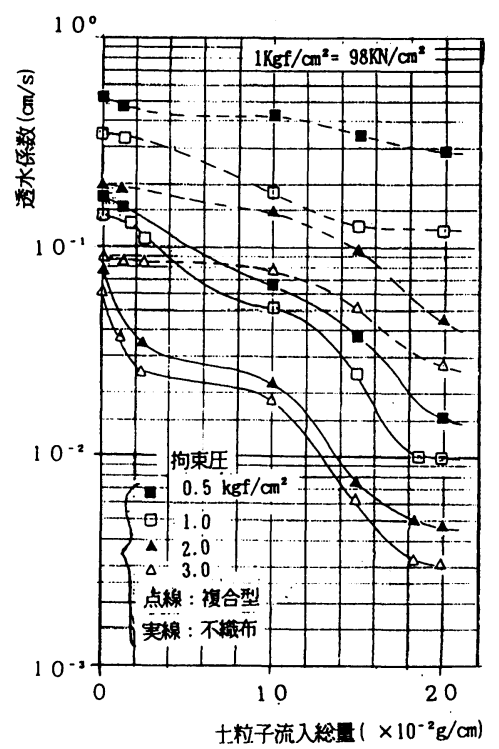

困一9流入土粒子湌量と面内方向透水保数

る.

c）排水層の透水俰数 $k_{n}$ の算定

排水層の排水能力に関係する各設計対象時期での $\mathrm{k}_{\mathrm{h}}$ の算定值は次のようになる.

(1)初期段階時期の排水層の透水係数

初期段階時期は盛土による圧密沈下速度が最大になる 時期で，一般に盛十開始後約 1 〜 2月前後と考えられ るので, 排水層の透水係数はある程度目詰りによる透水 性低下が生じているが, その低下量は少ないのでこれを 無視することとする.

従って，ここでは排水層の透水係数を実状より大きく とっている. このため, この初期段階時期においてごく 一時的に排水能力が不足することがあり得る.

この結果，一時的に排水層上流端の水位力許容值の1. $5 \mathrm{~m}$ を越えることとなるが, ごく短期間に限られるので一 時的な水位の上昇を許容することにする.

このことから，上流端から下流端までの透水係数は同 じとし,この時期の上載応力のもとでの目詰り発生前の 透水俰数とする.

(2)最終安定段階時期の透水係数

最終安定段階時期での排水層の目詰り後の透水係数の 
分布は別の研究結果 ")で示したように, 土粒子流入総量 の多い下流端に近いほど著しく低下する.

現場の排水層の透水係数の分布を既に提示した目詰り 試験から設定する.

このため目詰り試験での供試体の長さ及ひ現場の排水 層の集水分担長を 図一8 に示すような寸法此で 4ブ ロックに分割する.

現場排水層の下流端での土粒子流入総量を土粒子流入 負荷量と集水分担長との積から求める. そして現場の各 ブロックの土粒子流入総量を上記の下流端での土粒子流 入総量と上流端からの寸法比 $\beta$ （図一8に示す）と の積から求める.

こうして求めた現場のブロック A， B，C，Dの土粒 子流入総量に対応する現場排水層の透水俰数 $\mathbf{k}_{\mathbf{i}}$ を予め 目詰り試験から求めた土粒子流入総量と面内方向透水係 数との関係図 (2.（4） d) で前述) から求める.こ の現場の各ブロックの透水係数 $\mathrm{k}_{\mathrm{i}}$ から現場排水層の透 水係数 $\mathrm{k}_{\mathrm{n}}$ を求めるには式 $(4-2)$ による.

図-9 は不織布と不織布複合型の比較的透水性のよ い排水材の土粒子流入総量と面内方向透水係数との関係 を示す. 他の排水材については目詰り試験により求める.

なお現場の集水分担長が決定している場合の目詰り試 験は供試体の下流端に所定の土粒子流入総量を流入した 後, 各ブロック別の透水俰数の測定は必要でなく, $30 \mathrm{~cm}$ の供試体の透水係数のみを測定すればよい.

流入水は表面流入・面内流下条件で流入し排水される が, 上流端付近以外は面内方向の流量が卓越することか ら次式を採用する.

排水層の各ブロックの長さと透水係数をそれぞれ $\mathrm{L}_{1}$, $\mathrm{k}_{\mathrm{n} 1}, \mathrm{~L}_{2}, \mathrm{k}_{\mathrm{n} 2}, \cdots \mathrm{L}_{4}, \mathrm{k}_{\mathrm{n} 4}$ とし, 排水層の透水係数を $\mathrm{k}_{\mathrm{n}}$ とすると,

$$
\begin{gathered}
\mathrm{k}_{\mathrm{n}}=\mathrm{L} /\left(\mathrm{L}_{1} / \mathrm{k}_{1}+\mathrm{L}_{2} / \mathrm{k}_{2}+\right. \\
\left.+\mathrm{L}_{4} / \mathrm{k}_{4}\right)
\end{gathered}
$$

\section{d）排水層上の最高水位の設定}

排水層の排水能力を設定するときは排水層の上流端に おける最高水位を設定する必要がある. しかしこの最高 水位か高すぎると盛土法面の安定や軟弱な基礎地盤の圧 密速度が遅くなる問題が生じることになる.

最高水位は経験上 $1.5 \mathrm{~m}$ 程度であればよいとされている 但し, 排水層の排水能力が不足するときは $1.5 \mathrm{~m}$ 以上にな り得るので, 設定最高水位を越えないように排水能力を 変更することが必要となる.

この場合, 変更後の最高水位が1.5m以下にあるかどう かを確認するには式 (4-5) により判定する.

排水層の上流端よりの距離を $\mathrm{x}$ とし, 水位をy とし, 設計対象時期の排水層全体の透水係数を $\mathrm{k}_{\mathrm{h}}$, 流入水量を $\mathrm{q}$, 排水層の厚さ $\mathrm{d}$, 排水層上流端の最高水位を $\mathrm{y}_{\max }$ と すると,

$$
\mathrm{k}_{\mathrm{h}}(-\mathrm{dy} / \mathrm{dx})=\mathrm{q} \cdot \mathrm{x} / \mathrm{d} \quad(4-3)
$$

境界条件 : $\mathrm{x}=0, \mathrm{y}=\mathrm{y}_{\max } \quad \mathrm{x}=\mathrm{L}, \mathrm{y}=0$ となり, 両辺を積分して,

$$
\begin{aligned}
& \mathrm{y}=\mathrm{q} /\left(2 \quad \mathrm{k}_{\mathrm{h}} \cdot \mathrm{d}\right) \times\left(\mathrm{L}^{2}-\mathrm{x}^{2}\right) \\
& \mathrm{y}_{\max }=\mathrm{q} \cdot \mathrm{L}^{2} /\{2(\mathrm{k}-4)
\end{aligned}
$$

\section{e）排水碹の動水勾匟の算定}

排水層の動水勾配は集水分担長を $\mathrm{L}$ ，上流端と下流端 との水頭差を $\Delta \mathrm{h}$ とすると動水勾配 $\mathrm{i}$ は次式で示される

$$
\mathrm{i}=\Delta \mathrm{h} / \mathrm{L}
$$

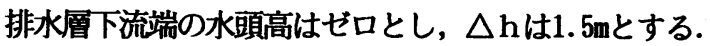

\section{5. 排水樰の設計}

先ず排水層の敷設構造，鉛直間隔，排水材とその厚さ を選定し，集水分担長を設定する. そして排水層に流入 する流入水量と集水分担長から総流出水量を求め, 各排 水層について定めた設計対象時期における拘束圧と土粒 子負荷による排水層の通水性能低下を考慮して, 排水層 上の許容最高水位のもとで, 排水層か棇流出水量以上の 排水能力を有するように排水層の層厚, 集水分担長等の 設定値を調整する.

実際の設計手順は 困一6 のようになるので，これ に従って述べると次のようになる.

\section{（1）排水層の教設構造}

盛十基礎地盤が良質の場合は 困一2（A） の部分 敷設構造を選定し, 軟弱な粘性土の場合は 四一2

（B）の敷設構造とし、盛十底面には全面敷設する. 盛十中に敷設する排水層は部分敷設構造とする. 部分敷設の場合の排水層の長さ、鉊直設置間隔は4.

(1) により選定する.

\section{（2）設計対象時期の決定}

設計検討が必要な時期は4．（3）に述べた通りであ る. 即ち良質の盛十基礎地盤上と盛十中に敷設する排水 層の場合には盛土完了後の最終安定段階のみを設計対象 時期とする.

軟弱な基礎地盤上に敷設する排水層の場合の設計対象 時期は 4. （3）b）に述べたように3種がある. 第1 のものは盛土の沈下速度が最大となる初期段階時期, 第 2 は通水性能か”最小となる盛十完了後の最終安定段階時 期, 第3は盛十完了前に最終安定段階に達する場合には その時期とする. この最終安定段階到達時間は 図一7 により求める.

\section{（3）設計対象時期における流入水算定}

各設計対象時期における流入水量の算定は浸透水のみ が流入するときは浸透水量とし, 浸透水と厈密排水とが 
流入するときは両者を合わせたものとして 4.（4）に より求める.

\section{（4）集水分担長}

敷設構造が 図-2（A） 及び（B） の盛土中 に敷設する場合, 排水層の長さが集水分担長となり, こ の集水分担長において必要な排水能力を満足するよう排 水材を選定する.

しかし排水能力が不足する場合には 図一2（B） の盛土底面に敷設する方法により排水パイプの間隔を調 節して排水能力を満足するよう集水分担長を設定する. 集水分担長は下流端での総流出水量, 土粒子流入総量, 動水勾配に影響する.

困一2（B） の軟弱な基礎地盤上に排水層を敷設す る場合, 集水分担長は排水パイプ設置間隔の $1 / 2$ となり, 排水能力が総流出水量より若干大きくなるように試行錯 誤により集水分担長を設定する.

これまでの経験から，集水分担長はおおむね約 $5 \mathrm{~m}$ 程度 である.

\section{（5）設計対象時期での総流出水量}

総流出水量の算定は各設計対象時期おける流入水量と 集水分担長との積により求める.

\section{（6）排水層の排水能力}

排水能力は各設計対象時期において, 式 (4-1) に より求める. 即ち層厚は各設計対象時期において設定し た拘束圧 (載荷応力) のもとでの值を用いる.

拘束圧は良質の盛土基礎地盤上と盛士中に敷設の場合 排水層の鉛直間隔の $1 / 2$ の土被り圧とし, 排水層が 1 層 の場合は全盛土厚の $1 / 2$ の荷重とする.

軟弱な基礎地盤上に敷設する排水層では, 本体底面部 は各設計対象時期の盛十高さ相当荷重とし, 法面底面部 は本体部の $1 / 2$ とする. この場合, 本体底面部の拘束圧 の作用幅は盛土の天端幅に盛土高さの $1 / 2$ を左右に加え たものとする.

透水係数は設計対象時期に応じて 4.（5）c）の(1) または(2)を用いる. また動水勾配 $\mathrm{i}$ は式 $(4-6)$ で求 める.

\section{（7）排水層の排水能力と総流出水 量との比較}

各設計対象時期における排水層の下流端での総流出水 量を支障なく排水するためには排水層の排水能力か総流 出水量以上となることが必要である.

\section{（8）排水能力か不足又は過大になったときの処置}

排水層の排水能力が不足又は過大になったとき, 次の ような好置をする.

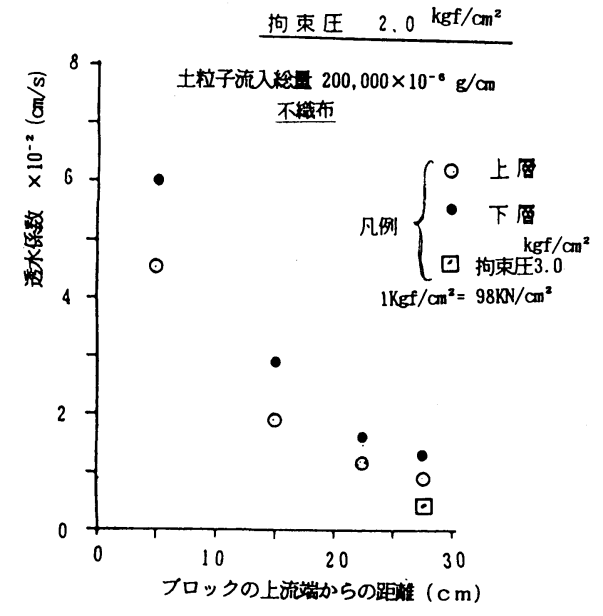

四一10 上，下算のプロック別面内方向 透水俰数の分布

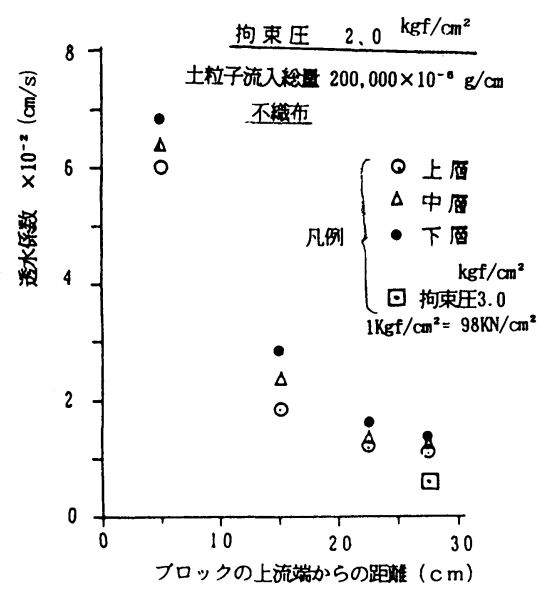

図-11 上, 中, 下層のプロック別面内方向 䅎水係数の分布

\section{a ) 集水分担長の変更}

敷設構造は 図一2（B） の軟弱な基礎地盤上の全 面敷設の排水層については集水分担長を変更することに より総流出水量と排水能力を調整する.

\section{b) 排水材の厚さの变更}

通水性能を変えるために層厚を変更するとき, 選定し た排水材に厚さの選択が可能な場合は適当と思われる厚 さのものを選定する. しかし層厚の不十分なものしかな い場合は，既に選定した排水材を複数層に敷設すること により層厚を増やす方法がある.

この場合, 拘束圧の大きさによっては排水層の目詰り後 の通水性能が層数倍以上となることがあるので, これに ついては6. で述べる方法により調査する.

\section{c) 排水材の変更}

a）b）を变更しても設定した排水材の通水性能の不 足及び過大を調整できないときは, その排水材の変更は 
2.（2）を参考とする.

\section{6. 排水層を複数層に敷設したときの通水性能}

これまでは排水層が 1 層の場合を取り扱ってきたが, 排水層を複数層に敷設した場合, その通水性能は不明な ので今回不織布について調査した. 不織布 (利加ヒンの 太い䄉維）を上，（中）, 下の2層又は3層に重ねて敷 設した場合の排水材の目詰りによる通水性能の低下につ いて, 1 層の場合と同様の方法によって試験を行なって 検討した.

図一 10 は30cmの不織布の供試体を2層に敷設し 2 $\mathrm{kgf} / \mathrm{cm}^{2}$ の拘束圧のもとで下流端で $200,000 \times 10^{-6}$ $\mathrm{g} / \mathrm{cm}$ になる土粒子流入総量を負荷したときの面内方向 透水係数の分布を示す. 土粒子流入総量が多い下流端に 近いほど透水係数は低下するが, 土粒子の流入面である 上層材の方が下層材よりも透水係数の低下は著しい

現場の排水層は下流端付近の透水性か著しく低下し問 題となるので, 供試体の下流端のAブロック（ $5 \mathrm{~cm}$ の平 均位置 $2.5 \mathrm{~cm})$ に着目すると, 1 層のときの同条件で同位 置の透水係数 $(\mathrm{cm} / \mathrm{s})$ は $5.4 \times 10^{-3}$ に対し2 層では上層 材 $9.0 \times 10^{-3}$, 下層材 $1.3 \times 10^{-2}$ となり, 1 層と比較 して, それぞれ1.7 倍, 2.4 倍の透水係数となる.

しかし拘束压 $3 \mathrm{kgf} / \mathrm{cm}^{2}$ の場合, 上層材, 下層材とも ほほ $5 \times 10^{-3}$ となり 1 層の場合とあまり差はない.

次に 2 層のときと同じ拘束圧, 土粒子流入総量のもと で3層に敷設した場合を 図-11 に示す.

3 層の場合も 2 層の場合と同様に土粒子の流入面に近 い上層材、中層材, 下層材の順に透水係数の低下か著し い. 2 層の場合と同位置での面内方向透水係数 $(\mathrm{cm} / \mathrm{s})$ は上層材 $1.1 \times 10^{-2}$, 中層材 $1.3 \times 10^{-2}$, 下層材 1.4 $\times 10^{-2}$ となり，1層の場合に比べると，それぞれ上層材 2.0 倍, 中層材 2.4 倍, 下層材 2.6 倍の透水係数となる. しかし拘束圧が $3 \mathrm{kgf} / \mathrm{cm}^{2}$ の場合, 敷設層数が 2 層, 3 層とも, 各層排水材の透水俰数は 1 層のときの $5.4 \times$ $10^{-3} \mathrm{~cm} / \mathrm{s}$ とほぼ近い値となる.

この理由として, $2 \mathrm{kgf} / \mathrm{cm}^{2}$ の拘束圧より $3 \mathrm{kgf} / \mathrm{cm}^{2}$ の 場合の方が排水層の層厚が減少して, 排水材の孔径が減 少することが考えられる.

このため上層材の目詰りが早期に発生するので, 残り の負荷量が下層材に流入して上層材に近い目詰り状況に なると推定される.

図-12 は上記の土粒子流入総量のもとで不織布を 1 層, 2層, 3 層に敷設したとき, 下流端ブロックAで の目詰り後の排水層の透水係数と拘束圧の関係を示す.

これによると透水係数は拘束圧が $2 \mathrm{kgf} / \mathrm{cm}^{2}$ では 2 層 の場合は 1 層の 1.5 倍, 通水性能は3.0 倍となる. 3 層 の場合は透水係数は2.2 倍, 通水性能 6.6倍となる.

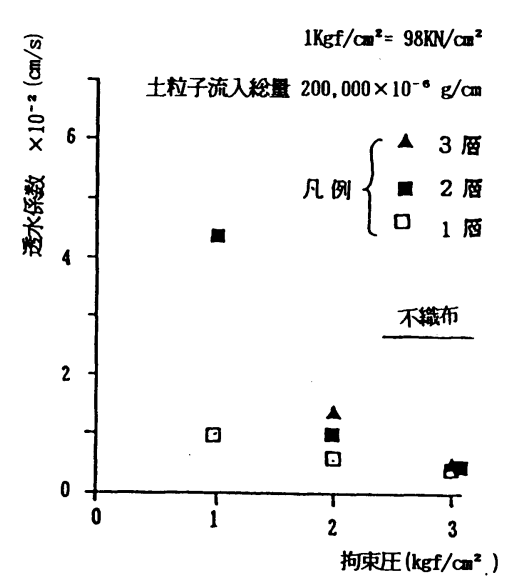

困-12 拘束圧と排水層の面内力向透水俰数

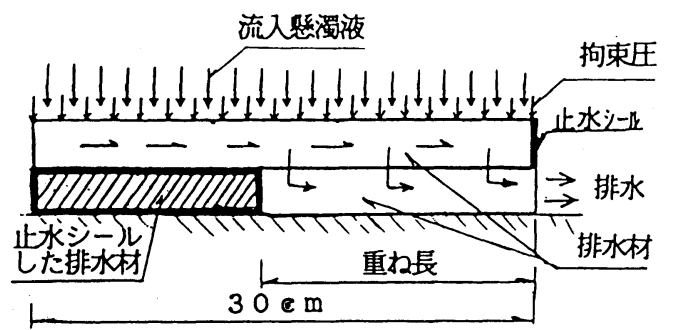

困一13重小样手供武体のセッ卜状况

しかし拘束厌が $3 \mathrm{kgf} / \mathrm{cm}^{2}$ になると, 2 層, 3 層の場 合も1 層のときとほぼ同じ透水係数となり通水性能は単 に層数倍だけ增大することとなる.

このような複数層の場合の通水性能の変化状況は排水 材の拘束圧による圧縮特性にかなり影響を受けると考え られるので, 使用する排水材について試験により確かめ ることが必要である.

\section{7. 排水層の粍手の設計}

これまでに述べた排水層の通水性能は排水層に継手の ない場合のものである. しかし実際上は一般に継手か泩 じるので通水性能に影響する可能性がある.

継手部は一般部の通水性能と同等の性能を有すること が合理的であり，このような継手部に設計すれば継手部 の影響を考慮する必要がなくなる.

継手の構造は一般に“重ね継手”が施工か簡単なため に採用されている.このため，ここでは一般部の通水性 能と同等の性能を有する重わ継手の “必要重ね長”につ いて調查し，重ね継手の設計法について述べる.

\section{（1）試鈋方法}

試験装置は既に述べた目詰り試験のものと同じである が, 図-8 に示すように30cmの供試体の重ね長を $15 ， 22 ， 30 \mathrm{~cm}$ 3 種類とする. また供試体のシール 


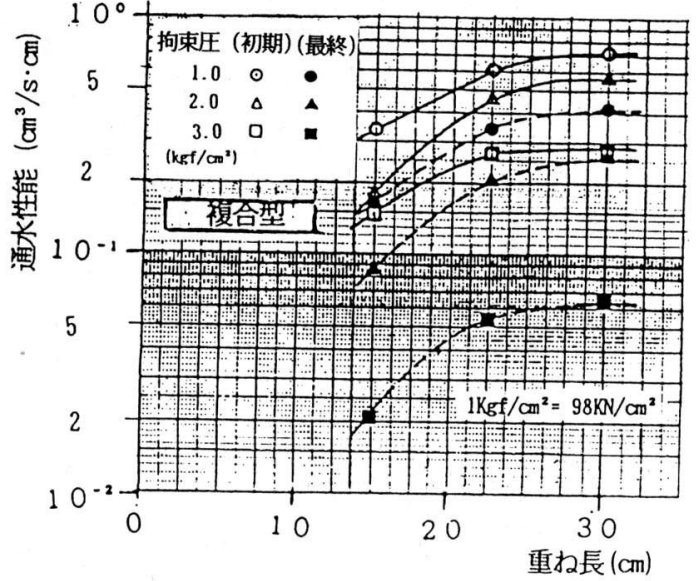

図-14 複合型の重小長と通水性能

は可塑性の止水材を使用する. 試験条件は 1 枚の排水材 の試験と同じで表- 1 に示す通りであり，土粒子流入総 量は 0 と $200,000 \times 10^{-6} \mathrm{~g} / \mathrm{cm}$ である.

試験方法, 試験条件とも継手試験としては安全側を考 慮したものに相当する. 従って, どのような位置で継手 が生じても差し支えない.

\section{（2）試験結果}

面内方向の通水性能の調査は比較的通水性能の大きい 不織布の複合型と不織布について目詰り試験により調査 を行った. 複合型と不織布の重ね長と通水性能の関係を 設計対象時期に当たる初期段階, 最終安定段階について それぞれ 図-14, 図-15 に示す。

複合型の継手の無い 1 枚の排水材の通水性能は拘束圧 が1.0，2.0，3.0 kgf/ $\mathrm{cm}^{2}$ において，それぞれ初期段. 階で $4.3 ， 4.0,2.9\left(\times 10^{-1} \mathrm{~cm}^{3} / \mathrm{s} \cdot \mathrm{cm}\right)$ となり, 最 終安定段階では，それぞれ2.6，1.9，0.63( × $10^{-1}$ $\left.\mathrm{cm}^{3} / \mathrm{s} \cdot \mathrm{cm}\right)$ となる. 従って 図一14 より, 必要重 ね長は初期段階でそれぞれ18.3，20.9，25.5cm, 最終安 定段階でそれぞれ $19.2 ， 21.9 ， 29.0 \mathrm{~cm}$ となる.

同様にして不織布についても 図一15 から必要重 ね長を求めることができる. 両排水材について拘束圧と 必要重ね長の関係を 図一16 に示す.

両排水材とも必要重ね長は拘束圧が大きいほど，また 初期段階よりも最終安定段階の方がより長くなっている

図-17 に拘束圧と透水係数比（鉛直方向透水係数 ／面内方向透水係数）の関係を示す.上記の場合に必要 継手長が長くなる理由として, 図より拘束圧が増加する ほど，また土粒子流入総量が増加するほど透水係数比の 低下が著しいことに起因すると考えられる.

\section{（3）必要継手長の決定}

必要重ね長は最終安定段階の場合の方が長くなるので

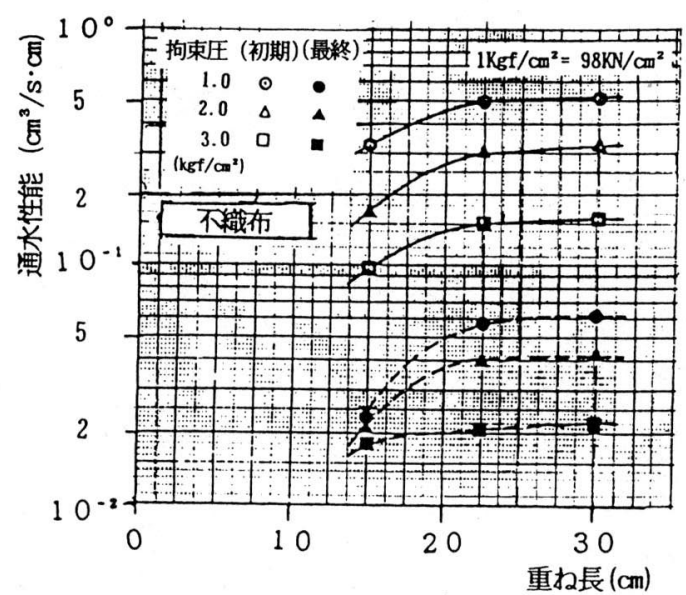

困一-15 不䢂布の重か長と通水性能

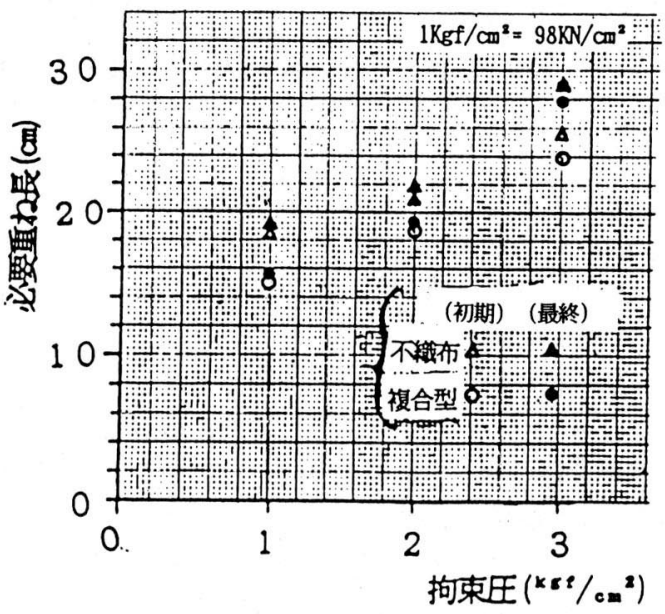

図-16 拘束圧と必要重ね長

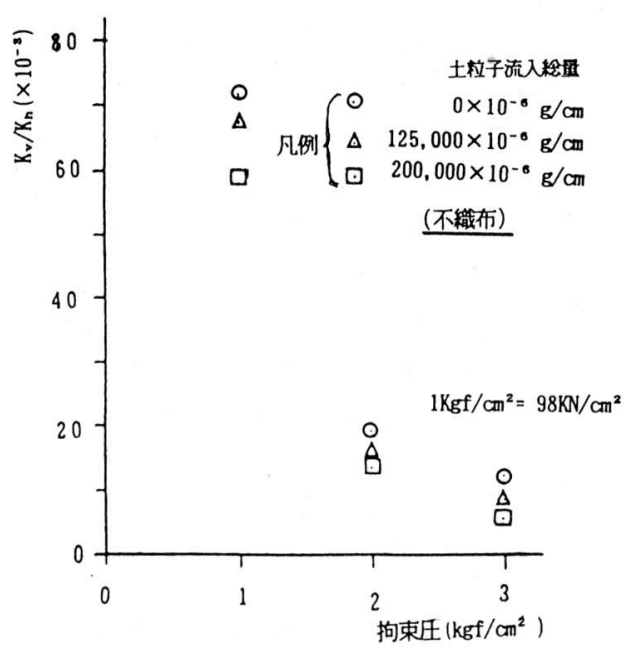

図-17 拘束圧と透水係数比 
この重ね長で決定する.

图一-16 より拘束厈 $3 \mathrm{kgf} / \mathrm{cm}^{2}$ では両排水材とも $30 \mathrm{~cm}$ 程度, $2 \mathrm{kgf} / \mathrm{cm}^{2}$ 以下では $20 \mathrm{~cm}$ 程度とすればよいと 思われる. また他種の排水材の場合には上記の目詰り試 酫を行なって必要重ね長を求めるのか望ましい.

実際の施工に対しては施工余裕長として必要重的長よ り5〜10cm長くすることが望ましい.

\section{8. 試験盛士による設計値の実則挨証}

本研究で提示した目詰りによる透水性低下を考慮した 排水層の設計方法の主体部を检証するために，この設計 方法に基ついて求めた最終安定段階時期における排水層 の通水性能とその到達に要する時間について現場実測值 と比較することにした. この現場実測は1978年のもので かなり前のものであるが, 現場試験による実証はその後 機会がないのでこの実測結果に基ずいて検証した.

\section{（1）試験盛士の排水層の経週時間と透水倸数の測定 結果}

筆者等がジオテキスタイル排水材をサンドマット工法 の代替工法として採用するに当たって1978年に流山市近 郊で試験盛土の際に軟弱な基䃈地盤上にサンドマット層 と不織布排水層を敷設して，それぞれ上流端での最高水 位 (間隙水圧計測定と水位観測)，盛士の沈下速度等に ついて調査した.

試験盛土の条件を 表-3 に, 盛十断面と排水層の 設置位置を 図一-18 に示す. 今回はその結果に基づ いて軟弱な基碳地盤上に敷設した不織布排水層とサンド マット層の面内方向透水㐿数を求めたものである.

この透水任数は盛土開始時からの経過時間毎に沈下速 度から圧密排水量を求め, 更に排水層の層厚, 集水分担 長, 排水層上流端の水位の測定値を用いて式 (4-5) から求めたものである. 従ってこの値は式 (4-1),

$(4-2)$ の排水層の透水俰数 $\mathrm{k}_{\mathrm{n}}$ に相当する.

面内方向透水俰数と経過時間の関係を 图-19 に 示す. 測定值は排水層の上流端水位の測定が可能となっ た時点から表示し，盛土開始日を原点とした。

盛土材は疑灰質粘土であり雨水の浸透水が排水層に浸 透する流速に当たる最終浸透能は試験から $8 \times 10^{-7} \mathrm{~cm} / \mathrm{s}$ とした.

一方, 压密排水の流入速度は実湘結果から $3 \times 10^{-5}$ $\sim 3 \times 10^{-6} \mathrm{~cm} / \mathrm{s}$ であり, これに比べて上記の雨水浸透 水の流入速度は非常に小さい. このため式 $(4-5) に$ よる透水俰数の算定は雨水による浸透水を無視している.

この 図-19 から不織布排水層, サンドマット層 とも時間の経過ととに透水俰数は低下し，それぞれ最終 安定段階に近いと思われる. 従って, 不織布の最終安定
衰一3 試满盛士の条件

\begin{tabular}{|c|c|}
\hline 試検期間 & 1978 年2 月1 日〜1979年9 月30日 \\
\hline 一次盛土 & 1978 年4 月21日～1978年4 月27日 \\
\hline 盛土高 & $4.4 \mathrm{~m}$ (一次盛土 $0.5 \mathrm{~m}$ 二次盛土 $3.9 \mathrm{~m})$ \\
\hline 盛土材 & 凝灰質粘土 \\
\hline 透水係数 & $1.6 \times 10^{-6 \mathrm{~cm}} / \mathrm{sec}$, 締固め含水比 $24 \%$ \\
\hline 基礎地盤 & 有機質粘十層厚 $6 \mathrm{~m}$, 垂直啋-ン $1 \mathrm{~m} \times 1 \mathrm{~m}$ \\
\hline 排水層層点 & $8.8 \mathrm{~mm} / 2$ 層（拘束厈 0. \\
\hline
\end{tabular}

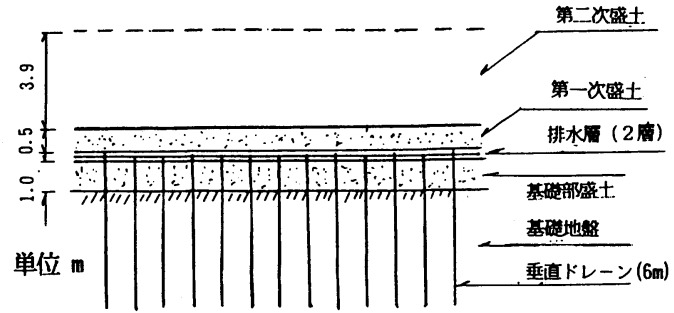

\section{困-18 盛土断面と排水層の設圆位量}

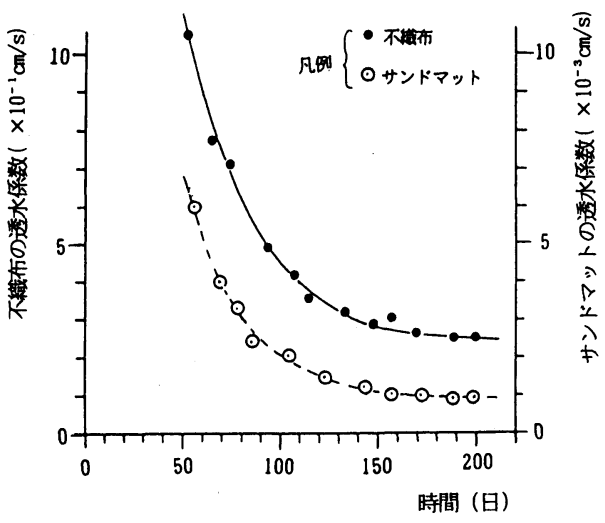

困一-19 経過時間と面内力向通水保数

段階での面内方向透水係数は約 $2.6 \times 10^{-1} \mathrm{~cm} / \mathrm{s}$ 程度 である.

\section{（2）本設計方法による最終安定段階の透水俰数とそ の到達時間}

不織布排水層は 図一18 に示したように盛十基礎 地盤上に直接敷設したのではなく，基礎地盤上に厚さ1m の盛土（凝灭質粘土）を行ない、その上に排水層を敷設 した.

その排水層上に高さ $0.5 \mathrm{~m}$ 盛土をしたものである. ま た基礎地盤からの圧密排水の多くは1mの基礎部盛土を貫 通して垂直ドレーンによりこの排水層に直接流入する. このようなかたちの排水層の敷設方式は本論文で取り扱 った盛十基礎地盤上の排水層敷設形式 困一2（B） とは異なっている.

従って，現場試験では排水層に下方から流入するもの 
は垂直ドレーンを通しての基礎地盤の圧密排水と1mの基 礎部盛土を通過して流入する圧密排水の浸透水もある.

この内, 後者の圧密排水による浸透水は基礎部盛士を 通過するため, 前者の压密排水（図一2（B） 相当） とは異なり排水層上部の盛土からの土粒子流入負荷量に 当たる量を有している.

この上部, 下部の盛土の厚さは $0.5 \mathrm{~m}$ と $1.0 \mathrm{~m}$ でかなり薄 いが, これまでの研究 ${ }^{11}$ から浸透水で土粒子流出に影

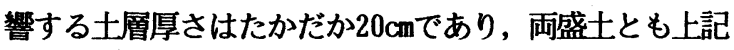
の層厚以上である.

排水層は上下に重ねて 2 層とし, 垂直ドレーンは上端 を曲げて 2 層の間に挟んでいるので土粒子流入負荷量は 上層, 下層とも同量とした.

このような試験盛十について排水層の最終安定段階到 達時間とその時期における面内方向透水係数を本設計方 法により求める.

\section{a）最终安定段階到達時間}

盛土材は凝灰質粘土であり盛士高さは4.4mであるが, 一次盛土として排水層の上部に $0.5 \mathrm{~m}$ 盛土を 1978 年 4 月 21日から27日まで施工し, 二次盛士の残り $3.9 \mathrm{~m}$ 層厚を 1979年5月17日から21日まで盛十をした.

この試験盛士のうち二次盛土分は 1 年の間隔があるの で本現場実測は一次盛土分だけで二次盛土分には無関係 である.

盛土に用いた凝灰質粘土を現場楴固め含水比 $24 \%$ で JIS 1210相当の締固めエネルギーで締固めたもので, 土 粒子流出試験 ${ }^{1}$ から求めた土粒子流入負荷量は $152 \times$ $10^{-6} \mathrm{~g} / \mathrm{cm}^{2}$ であり，また限界透水量は $0.7 \mathrm{~cm}^{3} / \mathrm{cm}^{2}$ で ある.（土粒子流入負荷量は試験を行なわないときは本 設計法では安全側の $390 \times 10^{-6} \mathrm{~g} / \mathrm{cm}^{2}$ を設定する)

地盤に対する雨水の浸透率は4．（3）b）(2)で既に 述べた $27 \%$ であるので, 限界透水量 $0.7 \mathrm{~cm}^{3} / \mathrm{cm}^{2}$ に相当 する浸透水が盛土に流入するためには26mmの降雨量が必 要となる.

試験盛十地点にごく近い気象庁我孫子锶測点での試験 盛土時期の観測記録 ${ }^{10)}$ から, 盛土開始時から総雨量が $26 \mathrm{~mm}$ となるまでの時間は0.5 ケ月である.

また排水層上の $0.5 \mathrm{~m}$ 盛土層厚を浸透水が降下浸透し て排水層まで到達する時間は盛十の最終浸透能が $8 \times$ $10^{-7} \mathrm{~cm} / \mathrm{s}$ あ゙あので24.1ケ月となる. これより盛十開始 から限界浸透量に相当する雨水が排水層に流入して最終 安定段階に達するまでの時間は24.6ケ月となる.

\section{b) 最終安定段階での面內方向透水俰数}

試験盛士に用いたポリオレフィン製の太い短縺維の不 織布について目詰り試験を行い, 土粒子流入総量と面内 方向透水係数との関係を求めた. その結果を 図一20 に示す.

垂直ドレーンの圧密排水から面排水層への土粒子流入

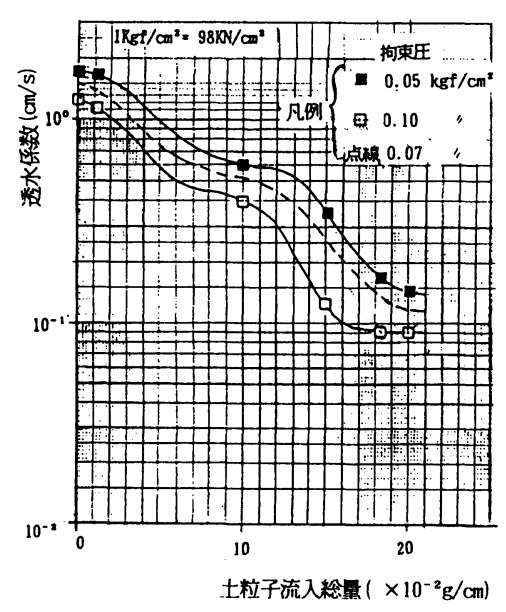

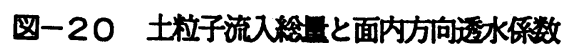

負荷量はドレーン長 $6 \mathrm{~m}$ で1mの正方形配置であるので, 2. (4) (2)に述べた算出方法により求めると $10 \times 10^{-6}$ $\mathrm{g} / \mathrm{cm}^{2}$ となる.

また上部，下部盛十からの土粒子流入負荷量がそれぞ れ152 $\times 10^{-6} \mathrm{~g} / \mathrm{cm}^{2}$ である. これより2 層排水層の上層 及び下層ともに土粒子流入負荷量は $(152+5) \times 10^{-6}$ $\mathrm{g} / \mathrm{cm}^{2}=157 \times 10^{-6} \mathrm{~g} / \mathrm{cm}^{2}$ となる.

排水管路間隔が25m であるので集水分担長は $12.5 \mathrm{~m}$ と なり, 下流端での土粒子流入総量は流入負荷量と集水分 担長 $12.5 \mathrm{~m}$ の積から196,000 $\times 10^{-6} \mathrm{~g} / \mathrm{cm}$ となる.

排水層の面内方向透水係数 $\mathrm{k}$ は場所により異なるが, 透水係数を4節（4．（5）c）（2）で述べた方法によ $\eta$ 図一20 から求める. この図は現場にシュミレー トした目詰り試験により求めたものである.

排水層の集水分担長を 図-8 に示す寸法此で A, B， C，Dの4ブロックに分割すると，Aブロックの下 流端での土粒子流入総量 $\left(\times 10^{-6} \mathrm{~g} / \mathrm{cm}\right)$ が196,000 で あることから，B，C，Dの土粒子流入総量はそれぞれ 163,000，131,000，65,000である.

これらのブロックの土粒子流入総量に対応する透水係 数を 図一20 の盛十高による拘束圧 $0.07 \mathrm{kgf} /$ $\mathrm{cm}^{2}$ について求めると, それぞれのブロックの面内方向 透水㐿数は下流端から上流端に向かけて1.2, 2.0，3.8, $6.3\left(\times 10^{-1} \mathrm{~cm} / \mathrm{s}\right)$ となる.

従って最終安定段階での排水層の透水係数 $\left(\times 10^{-1}\right.$ $\mathrm{cm} / \mathrm{s})$ は式 $(4-2)$ により, $\mathrm{K}_{\mathrm{n}}=1250 /(208 / 1.2$ $+208 / 2.0+417 / 3.8+417 / 6.3)=4.0\left(\times 10^{-1}\right.$ $\mathrm{cm} / \mathrm{s})$ となる.

目詰り前の初期值は図より $1.5 \times 10^{\circ}(\mathrm{cm} / \mathrm{s})$ であるの で, 約1/4 に低下したことになる.

\section{（3）試験盛土による検証桔果}

本設計方法により求めた值と現場測定值とを比較し次 
のようなことが判かった.

最終安定段階到達時間については試検盛士の湘定期間 の関係で十分な検証はできなかった. しかし 図-19 の時間と透水係数の関係において200 日 (6.7 ケ月) で の不織布、サンドマットとも透水保数は最終安定段階に 到達していないものの, かなりこの段階に近い状態に達 していると思われる. この場合，本設計法による計算值 の24.6ケ月との差は大きいが, この理由として次のこと が考えられる.

設計で求めた最終安定段階到達時間の24.6ケ月のうち 必要降雨量到達時間0.5 ケ月の最終降雨よりの浸透時間 は24.1ケ月である. しかし盛十層岸が䭂和状態，または それに近い場合は, 浸透速度か設計浸透速度の2 倍とな るので上記の浸透時間は12ケ月程度となる．また最終安 定段階到達時間は約13ケ月である.

現場状況は 図一18 に示すような軟弱地盤上の低 盛土であるため, 基礎地盤からの圧密で生じた上昇排水 により, 盛土部がほほ飽和状態にあったと考えられる.

このため上記の13ケ月が妥当と思われる. 現場実測で は200 日で最終安定段階に近いが, 図一19 の曲線 形状から完全な最終安定段階になるには更に50日程度が 必要と思われる. 従って現場の最終安定段階到達時間は 250 日（約 8.3 ケ月）程度になると考えられる.

このことから設計值は実測值の1.5 倍である.

また排水層に流入する土柆子流入総量にごく近い量が 負荷され最終安定段階に近いと思われる200 日時点での 本設計法による最終安定段階の透水係数 $4.0 \times 10^{-1} \mathrm{~cm}$ / s と本章 (1) に述べた方法による現場測定の透水係 数 $2.6 \times 10^{-1} \mathrm{~cm} / \mathrm{s}$ で約 1.5 倍程度の相違である.

以上の 2 項についての実測值に対する設計值の相違は いずれも1.5 倍程度であり, このような分野ではかなり 少ないと思われる.

今回の検証のための現場での試験盛土は 1 回だけであ るが, 本設計法の信頼度は許容されるべき範囲にあると 思われる.

\section{9. 結論}

ジオテキスタイル排水材を用いた軟弱な盛十基礎地盤 上や盛土中に敷設する排水層の設計方法はまだ殆ど見当 たらないので, 目詰りを考慮した排水能力と排水すべき 総流出水量から設計上最も箃しくなる設計対象時期にお いて処理できるような設計方法を提示した.

更に，この設計法に不可欠な排水材継手の必要重ね長， 排水材を複数層に敷設した場合の通水性能を実験により 明らかにし，その他設計上必要な選定項目，設定項目の 決め方についても考察し設計に取り入れた.

そしてこの設計方法の主体部を検証するために，この
設計方法に基づいて求めた最終安定段階における排水層 の通水性能とその到達に要する時間について現場実測値 と比較した. その結果検証のための試験盛土は 1 回だけ であるが本設計法の信頼度は許容されるべき範囲にある ことが推定できた.

今後はこれ迄と異なった排水材, 盛十基礎地盤, 盛十 材, 盛土高, 工事の地域等の条件において実測検証を積 み重ねたいと考えている.

\section{参考文献}

1）林英雄、森 比 : 盛土中に敷設するジオテキスタイル排水 材の目詰りによる透水性低下の予測に関する研究，土木学 会論文集. No. 510 , pp. $57 \sim 67,1995$.

2) 林英雄, 森 : 目詰りによる透水性低下に及涩す面排水 材の構造形式について, 土木学会 第49回年次学術諈演会 III, pp. $1462 \sim 1463,1994$.

3）林英雄. 茶山和博. 森 低下に関する実倹的研究，土質工学会 第25回土質工学研 究発表会. pp. $2009 \sim 2012,1990$.

4）林英雄, 茶山和博. 森 乱された粘性土の开密排水中 に含まれる土柆子㵂度と土柆子棇量に関する研究, 土木学 会 第49回年次学術誁演会而,pp.764 765，1991.

5）林英雄. 森

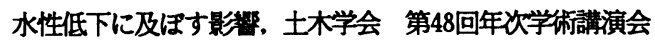
III, pp. $1146 \sim 1147,1993$.

6) 柩根 勇: 水文学, pp.167 168, 大明堂1975.

7) 山本䓅毅, 高桥 裕: 困説水文学, p.1, 自然科学書会, 1987.

8）地下水ハンドブック編集委員会 : 地下水ハンドブック. p. 22. 建設産業臹有会, 1979.

9）建設省河川局監修：河川砂防技術基準（案）， p. 150 , 1986.

$10 ）$ 銚子地方気象台: 気象月報（千葉県），1978.

(1996. 2. 23受付) 
ONE PROPOSAL ON THE DESIGN OF NONWOVEN GEOTEXTILE FILTER LAYER CONSIDERING PERMEABILITY DUE TO CLOGGING

$$
\text { Hideo HAYASHI and Akira MORI }
$$

Recently,geotextile filter materials are often used to from drainage layers within earthfill embankments amd at earthfill-foundation. This is because scarcity of traditional river- bed materials and concern over the environmental impact of using remaining resouces.

The geotextile filter material will become clogged soil particle over time, thus reducing its permeability. However, this drawback has not been considered in design up to this time.

We proposed an alternative method which carefully considers this reduction in permeability so its indispensable items, and incorporated the results of thorough field testing. 